\title{
Analysis of the Ways to Infiltrate Basketball Culture in Sports Basketball Training in Higher Vocational Colleges
}

Xianghua Hu

Guangzhou Pearl-River Vocational College of Technology, Guangzhou 511300, Guangdong, China.

Abstract: Cultural inheritance is one of the basic goals of education. In the physical education of higher vocational colleges, basketball culture, as an important part of culture, is also a part of education that should be inherited. At present, sports basketball training in higher vocational colleges is more of a single basketball skill teaching, focusing on the training of students' basketball skills and tactics. However, the teaching penetration of basketball culture is seriously insufficient, which is not conducive to the inheritance of basketball culture. It cannot play an active role in improving the basketball literacy of students in higher vocational colleges. In this regard, this article analyzes the connotation of basketball culture, combined with the current situation of basketball culture teaching in sports basketball training in higher vocational colleges, and explores the infiltration and development of basketball culture in sports basketball training in higher vocational colleges.

Keywords: Basketball Culture; Vocational Colleges; Physical Education; Basketball Training; Penetration

\section{The connotation of basketball culture}

With the successive holding of world sports competitions, sports become a new industry in the new era. More and more people are beginning to pay attention to sports. Basketball is one of the most popular sports events. The competition is relatively strong, so the popularity is relatively high. Basketball is one of the regular sports curriculum items in the current physical education of higher vocational colleges.

Basketball culture is actually the culture related to basketball. Basketball culture includes the spirit of basketball, such as the spirit of cooperation, unity, sports skills, and game systems. Basketball culture can also be understood from different angles. Basketball culture in a narrow sense refers to the experience and values that people obtain in basketball, including thoughts, consciousness, and concepts, which are beneficial to the physical and mental health of athletes. The broad sense of basketball culture refers to the use of basketball as a carrier, the values, sportsmanship and quality of individuals and teams.

In terms of the basic content of basketball culture, there are also many aspects, including material culture, spiritual culture and institutional culture. Basketball culture has a certain application value in education. With the help of basketball culture, the correct values and outlook on life can be conveyed to students, encourage students to progress, and promote the continuous improvement of students' ideological awareness and quality.

\section{The status quo of basketball culture teaching in sports basketball training in higher vocational colleges}

\subsection{Insufficient attention to courses and lack of basketball culture infiltration teaching}

At present, basketball training courses in higher vocational colleges are one of the basic physical education courses. For

Copyright $\odot 2020$ Xianghua Hu

doi: $10.18686 /$ ahe.v4i10.2891

This is an open-access article distributed under the terms of the Creative Commons Attribution Non-Commercial License (http://creativecommons. org/licenses/by-nc/4.0/), which permits unrestricted non-commercial use, distribution, and reproduction in any medium, provided the original work is properly cited. 
non-physical students, basketball courses are quality education courses and compulsory courses. However, the importance of basketball training courses is still insufficient compared to other professional courses. In sports basketball training in higher vocational colleges, teachers pay more attention to the teaching of basketball skills. In basketball classes, teachers will demonstrate basketball games to students. Ball movement, explain related movement skills and norms, formulate basketball rules, etc. However, most of the basketball teaching in higher vocational colleges does not take basketball culture as the basic content of student classroom teaching. Therefore, the current basketball culture is There is very little penetration in basketball training teaching in higher vocational colleges.

\subsection{Insufficient basketball culture penetration, teaching skills need to be improved}

At present, teachers do not have the awareness of penetrating basketball culture into basketball training, because teachers' understanding of basketball culture still has some limitations. Teachers cannot correctly view basketball culture in teaching. They feel that this kind of teaching content is unnecessary, leading to basketball Culture is ignored.

In addition, teachers do not sufficiently excavate basketball culture in basketball training and teaching. In basketball training and teaching, some teachers may want to infiltrate basketball culture, but they suffer from insufficient materials to infiltrate. Teachers' inadequate exploration of basketball culture in basketball courses has seriously affected the improvement of basketball teaching quality.

\subsection{The limited teaching ability of teachers affects the improvement of infiltration teaching quality}

On the whole, physical education teachers in higher vocational colleges have insufficient skills in teaching basketball culture. Many sports basketball training teachers do not have a high theoretical basis for their own teaching. Their basketball training and teaching emphasizes basketball skills rather than teaching skills. Therefore, relevant basketball teachers' own basketball culture teaching literacy and ability are not high, which affects they infiltrate basketball culture in basketball training.

\section{Effective countermeasures for the penetration of basketball culture in basketball training and teaching in higher vocational colleges}

\subsection{Innovative basketball culture infiltration teaching methods to stimulate students' interest in participation}

In the practice of basketball culture infiltration teaching in higher vocational colleges, teachers should try to innovate as much as possible the teaching form and content of basketball culture infiltration in basketball training and teaching, and pay attention to curriculum teaching reform and innovation. In the curriculum basketball culture teaching practice, actively do a good job in the reform and innovation of curriculum basketball culture teaching. For example, teachers can use effective organization and development of activities to allow students to participate in the teaching practice of basketball culture in the curriculum, feel the charm of basketball culture in the practical exploration, and experience some life philosophy, so as to independently acquire knowledge and strengthen the basketball culture. The understanding and grasp of the teaching content, the basketball teaching content grasped through practice, and the basketball culture experienced can be more impressive. On the one hand, it keeps students' strong interest in curriculum learning, and on the other hand, it is also conducive to promoting curriculum teaching reform and innovation. For example, in basketball training and teaching, teachers can organize students to carry out basketball games friendship league activities, through the game, let the participating players with a good mental outlook, superb skills, high morale, to present a scene of wonderful performances to the audience, fully Show the spirit of unity and progress among college students. The development of such activities can also vigorously promote the national fitness exercise, advocate a scientific, civilized, and healthy lifestyle, and create a strong overall fitness atmosphere. Activities not only enrich the students' amateur cultural life, enhance their physical exercise, enhance their awareness and sense of collective honor, enhance team cohesion, but also regulate the rhythm of work of college students, promote sports and cultural exchanges between brother colleges, and enhance the relationship between brother colleges. The friendship between the two embodies the spirit of unity, cooperation, and struggle, and allows college students to devote themselves to future studies with full enthusiasm. Relevant vocational colleges learn from each other, make progress together, and create a positive and healthy 
basketball culture atmosphere, which also plays an important role in promoting basketball culture infiltration teaching.

In this regard, relevant higher vocational colleges should continue to carry out various basketball cultural and sports activities, enrich the cultural construction of the base of higher vocational colleges, enrich students' sports and cultural life, promote student communication, show a healthy, progressive, and enterprising college student style, and comprehensively improve college students The cohesion and centripetal force of the team, based on their own duties, bravely shoulders heavy responsibilities, and exerts the education function of basketball culture.

\subsection{Actively explore basketball culture and prepare for infiltration teaching}

In the new era, in the practice of permeating basketball culture in basketball training and teaching in higher vocational colleges, there must be sufficient basketball culture teaching materials to be able to continuously infiltrate basketball culture teaching concepts in basketball training courses and promote teacher courses basketball culture teaching level has been continuously improved.

In the current basketball training courses of higher vocational colleges, teachers have insufficiently explored the teaching content of basketball culture, and have not fully utilized the important value of basketball culture in the teaching of basketball training courses. Basketball culture teaching cannot be realized in every basketball session. In this regard, in order to infiltrate more basketball culture teaching materials in basketball training courses, teachers must actively explore the connotation and value of curriculum basketball culture in basketball training courses, and do adequate basketball culture teaching design work. To moisten things silently, so that students can strengthen their comprehensive literacy in aesthetics study and improve basketball culture level.

\subsection{Carry out basketball teacher training to improve infiltration teaching skills}

The penetration of basketball culture in basketball training and teaching is determined to a certain extent by the teaching quality and ability of course teachers. At present, in the relevant basketball culture teaching penetration, teachers have insufficient grasp of the key points and skills of basketball culture penetration teaching, and the quality of penetration teaching is limited. In this regard, it is necessary to further strengthen the training and training of basketball teachers to improve the curriculum design ability of basketball teachers. Promote the continuous improvement of the quality of basketball culture in the teaching of basketball courses.

\section{Conclusion}

The penetration of basketball culture in the teaching of basketball training courses is of great significance and has a positive effect on the development of basketball courses and the promotion of quality education. At present, there are still some problems in the penetration of basketball culture in higher vocational colleges. In this regard, it is necessary for higher vocational colleges to deepen the development of basketball culture teaching, dig out effective basketball cultural materials, change course teaching models and methods, and improve the emphasis on culture also improves the basketball teachers' cognition and teaching skills of basketball culture, promotes the effective penetration of basketball culture in basketball training and teaching, and enhances the role of basketball culture in promoting the quality education of students in higher vocational colleges.

\section{References}

1. Wang Z, Li C, Liu D. Analysis on the status quo of basketball culture development in "China Basketball City"Research on the status quo of basketball culture development in Fuxin. Journal of Guangzhou Sport University 2009; 29(06): 30-33.

2. Gao Z, Li L, Zhang S. Research on the dilemma and strategy of youth campus basketball characteristic school culture construction from the perspective of sports power. Sports Science and Technology Literature Bulletin 2020; 28(05): 100-102.

3. Zhu C, Yu W. Analysis on the construction path of basketball cultural system in higher vocational colleges in the new era-Taking Leshan Normal College as an example. Journal of Leshan Normal University 2020; 35(04): 136-140.

4. Li J, Zhao J. The influence of college basketball culture on the reform of basketball teaching in higher vocational colleges and suggested strategies. Sports World (Academic Edition) 2019; (10): 84+83. 